\title{
Soft skills influencing motivation and their impact on the employee performance: An Indonesian company case
}

\author{
Cheng-Wen Lee, Alum Kusumah
}

\begin{tabular}{|c|c|c|}
\hline \multicolumn{3}{|c|}{ A B S T R ACT } \\
\hline \multicolumn{3}{|c|}{$\begin{array}{l}\text { Objective: The importance of this study in bridging the gap between existing research } \\
\text { literature works of soft skills, motivation and employee performance, and offering an } \\
\text { empirical reference to the industry's experience. }\end{array}$} \\
\hline \multicolumn{3}{|c|}{$\begin{array}{l}\text { Research Design \& Methods: This study reflects an empirical analysis by taking } \\
\text { a quantitative approach to finding and demonstrating the degree of the influence of } \\
\text { variables on the proposed hypotheses. }\end{array}$} \\
\hline \multicolumn{3}{|c|}{$\begin{array}{l}\text { Findings: The variables of soft skills, i.e. interpersonal skills and intrapersonal skills } \\
\text { have shown a positive influence on motivation and a positive impact on employee } \\
\text { performance. These variables have a continuous effect on the overall performance } \\
\text { of the company. The analytical results represented empirically through the path } \\
\text { analysis conducted in this study. }\end{array}$} \\
\hline \multicolumn{3}{|c|}{$\begin{array}{l}\text { Contribution \& Value Added: This study emphasizes the creation of understanding } \\
\text { among companies, primarily to strengthen soft skills that go hand in hand with grow- } \\
\text { ing hard skills, to promote encouragement to take the effect of the overall perfor- } \\
\text { mance of employees and organizations to thrive and indeed grow in the current era } \\
\text { of global competition. }\end{array}$} \\
\hline Article type: & & \\
\hline Ke) & & \\
\hline odes: & & \\
\hline & & \\
\hline
\end{tabular}

\section{Suggested citation:}

Lee, C.-W., \& Kusumah, A. (2019). Soft kills influencing motivation and their impact on the employee performance: An Indonesian company case. International Entrepreneurship Review (previously published as International Entrepreneurship / Przedsiębiorczość Międzynarodowa), 5(4), 123-140. https://doi.org/10.15678/IER.2019.0504.08

\section{INTRODUCTION}

Manufacturing firms are largely dependent on humans and machines in carrying out their operations and in their efforts to increase the efficiency of their businesses. In addition to increasing the need and awareness of manufacturing industries in the province 
of Riau, Indonesia in general, and the pulp industry in particular. To address the needs of trained and skilled human resources to meet employers' demands in the face of global challenges, particularly in the smart factory challenge and intelligent technology embodied in Industry 4.0 links across diverse aspects of human life. By implementing this application, the manufacturing technology has achieved the inclination towards machine automation and data exchange. This has changed other areas of human life, such as the economy the world of business and lifestyle.

The changes introduced with all the implications make the manufacturing sector more compact and efficient. However, other implications, such as the propensity to minimize the use of human resources, are due to the substitution by machines or robots. Employee burnout, work stress, health issues, and problems in managing work duties and private life are extremely relevant challenges nowadays. Such a scenario leads to HRM being rethought whether companies are willing to have the workers in the future to run the business. Some scholars argue that sustainable HRM could serve as a possible solution to restore humanity to HRM (De Prins et al., 2014), while sustainability refers to regeneration, development, and renewal of resources (Ehnert, Harry, \& Zink, 2013). The need for continuous improvement of employee skills, both soft skills and hard skills, is unavoidable in the presence of these changes. The attributes of soft skills and hard skills play a crucial role in assessing the success of the employee. Nevertheless, aspects of hard skills (technical skills) are more concerned than aspects of soft skills, and vice versa. Besides, what should be necessary for this global era remains an innovative approach between hard and soft skills.

A report published in January 2015 by a global economic research institute (The Development Economics), which reported that in most cases, if not all, modern workplaces, the contribution of soft skills arises from the significance of collaboration, teamwork, worker interactions. Survey responses from senior business leaders that soft skills matter to the vast majority of companies. For instance, a recent survey of businesses undertaken in the U.S discovered that communication skills (83\%) and the ability to work within a team (74\%) are among the top three qualities employers are currently looking for in new workers. The purpose of this study is to explore the direct and indirect effect on the motivation of soft skills and their effects on employee performance, primarily in the pulp industry.

\section{Problem statement}

This study based on the phenomenon identified during the pre-research activities conducted at the PMP Company. The PMP Company has implemented a policy of rationalization of employees following the implementation of a production automation program. Consequently, the initiative to rationalize the number of employees removes $50 \%$ of the total number of employees by investing in the procurement and upgrading of equipment and manufacturing machinery. The management of PMP Company strives to maintain and improve the morale and skills of its employees. In particular, the study aimed at identifying the degree to which the soft skills (interpersonal and intra-personal skills) possessed by employees of PMP Company affect their motivation to perform their work and have an impact on the performance of their employees. Subsequently, the question addressed through this analysis is whether soft skills have a positive influence on motivation to have a positive impact on employee performance. 


\section{Research gap}

There are several studies on soft skills, motivation, and employee performance. Nonetheless, there are gaps where only a few empirical and relevant types of research are carried out in the manufacturing sector, especially in the pulp manufacturing business, which is introducing programs to streamline the number of employees, modernize and automate production lines. This phenomenon can affect the degree of employee morale and knowledge of developing employees' skills in the Industry 4.0 paradigm.

\section{LITERATURE REVIEW}

\section{Soft skills definition and attributes}

Soft skills in the 20th century are a major differentiator, a vital factor of employability and life achievement. Soft skills are characterized as competence and ability to manage themselves properly and to establish successful relationships with others (Muqowim, 2012). Therefore, as explained by Muqowim, soft skills have an intrinsic ability to succeed in doing work, where soft skills have also been defined as personal and interpersonal behaviors needed to develop and optimize human performance. Soft skills are the ability to deal with others (interpersonal skills) and the ability to manage oneself (intrapersonal skills) to work effectively and efficiently (Firdaus, 2017). Employers now attach great importance to interpersonal and intrapersonal skills and offer technical skills somewhat less weight (Vijayalakshmi, 2016). Soft skill is a concept associated with a collection of personal, positive attributes that improve the relationships, work performance, and market value of an individual. Through learning soft skills, each person can adapt to the environment and to any transition that occurs in thinking, talking and acting following relevant norms (Okoro et al., 2017).

Interpersonal skills are needed to be successful in their personal and professional lives. Interpersonal skill is an ability to properly understand and react to other people's feelings, attitudes and behaviors, inspiration, and desires. How someone can create harmonious relationships by understanding people or others and reacting to them (Robbins et al., 2012). Interpersonal skills are abilities related to the community group's social environment or work environment and individual experiences. Some interpersonal skills examples include; communication skills, leadership skills, negotiation skills, public speaking skills, and teamwork (Firdaus, 2017).

Intrapersonal skills are the abilities in an individual's mind. The other end of this axis is the interpersonal skills that relate to people's relationships or communication (Vijayalakshmi, 2016). Intrapersonal skills are self-regulating skills. Before someone forms a relationship with another person, these abilities are essential. Some examples of intrapersonal skills include the transformation of character, time management, confidence, and proactive capacity (Firdaus, 2017).

\section{Motivation}

Work motivation was shown to be connected to the provision of service quality by enhancing employee productivity and leading them to individual and group goals (Kaba et al., 2013). Work motivation is a collection of energetic elements that arise both within and beyond the being of an individual, initiate work-related action, and determine its shape, path, duration 
and intensity (Pinder, 1998). Motivation is widely considered one of the most essential determinants of successful employment (Dietrich, Parker, \& Salmela-Aro, 2012).

Most of the last half of the 20th century, work motivation theories were closely aligned with a performance-centric perspective that focuses almost primarily on motivation as a proximal determinant of employee performance (Kooij \& Kanfer, 2019). Over the past decades, however, improvements in the nature of work and advancements in motivational theorization have extended and emphasis to include a person-centered perspective that emphasizes the multi-level motivational processes which naturally occur and affect the individual's constructive role and behavior and the creation of his / her work (Kanfer \& Chen, 2016). Modern work motivation concepts explain how people act, and the factors that influence job initiation, orientation, strength, and persistence (Kooij \& Kanfer, 2019).

\section{Employee performance}

Performance is a notion that describes how an individual can use his or her potential or actual knowledge skills to achieve his or her own goals or expectations (Altındağ \& Kösedağı, 2015). Employee performance refers to the task-related behavior required of an employee and how they are performed (Goodall Jr., 1992). The factors that include an employee's productivity include happiness, sluggishness, enthusiasm, and dedication to work; while employee fulfillment implies employee satisfaction when he/she is at work (Anderson, Rungtusanatham, \& Schroeder, 1994). Employee performance is important to the company because it is a reflection of the success of the organization (Sadikoglu \& Zehir, 2010). It evaluates the non-financial indicators of a company such as teamwork, motivation, productivity index, service quality and competency (Manzoor et al., 2011). Employee performance has been found to increase organizational productivity indirectly through innovation as employees generate ideas for new products or services to increase the competitiveness of the business (Sadikoglu \& Zehir, 2010).

Traditionally, organizational success has been calculated using financial metrics such as income, the share of the market, profits, and rate of growth (Demirbag et al., 2006). However, non-financial indicators, which are usually developed in line with human resources outcomes such as turnover, absenteeism, job satisfaction, productivity, and quality, must also be taken into consideration (Abdalkrim, 2013). Employee performance is about how employees achieve organizational objectives (Imran et al., 2012) as well as the timely, effective and efficient fulfillment of organizational goals (Osman et al., 2016).

\section{Previous study}

Cimatti (2016) conducted research on manufacturing firms in the USA, studied and examined soft skills as personal transversal competencies such as communication skills, teamwork, social interactions and other personality traits that form individual characteristics in their positions in organizations. The results of the study showed that soft skills are a strategic and essential component for a professional to support the business by building an effective team and working environment to boost the competitiveness of the organization. Cimatti also emphasized the importance of organizations to choose and improve human resources with the best soft skills, so that enterprises can work effectively and efficiently to deliver products and services in line with what is provided, including in sectors where technology plays a critical role. 
Dean and East (2019) performed a study on logistics companies in New Jersey, USA. This study showed that hard skills are not enough for workers to compete in a globally competitive environment and soft skills are a need and consider being of utmost importance. Seetha, 2014) studied several multinational companies in Malaysia engaged in manufacturing, stating that the firms' management valued soft skills is more than hard skills. Employers, however, see a lack of staff equipped with deep intellectual capacities and practical skills to be able to carry out their jobs in a more job-oriented manner. Employers claim that to develop a learning organization the workforce is equipped with soft skills other than hard skills.

From the results of their research on employees working in the home accessories and porcelain industry in Indonesia, Hendarman and Tjakraatmadja (2012) revealed that soft skills are needed for technical innovation. Soft skills in this study have a positive impact on technical innovation that is needed to create new products or services. Furthermore, Hairi et al. (2011) conducted a study focusing on the soft skill requirements needed by entrepreneurs from 150 local and multinational companies in Malaysia and found that soft skills are also required and rated "important" by Malaysian employers.

\section{Research hypotheses and framework}

The proposed research hypotheses framework to examine are as follow:

Hypotheses:

H1: Intrapersonal skills and interpersonal skills have a positive influence on job motivation.

H2: Intrapersonal skills and interpersonal skills have a positive influence on employee performance.

H3: Intrapersonal skills and inter-personal skills through work motivation have a positive impact on employee performance.

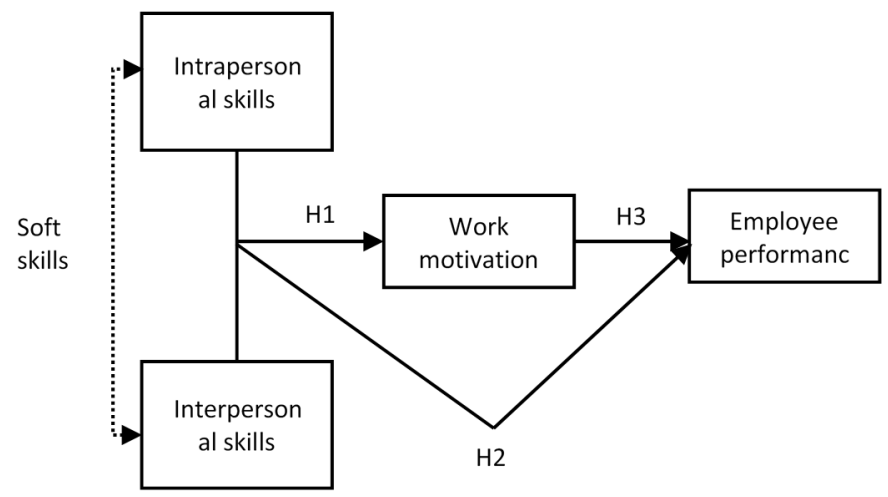

Figure 1. Research framework

Source: own elaboration. 


\section{RESEARCH METHODOLOGY}

This study reflects an empirical analysis by taking a quantitative approach to finding and demonstrating the degree of the influence of variables on the proposed hypotheses. The quantitative analysis starts with validity and reliability testing where both types of tests are required to determine the level of validity of the questionnaire and to evaluate the degree of stability, consistency, predictive capacity and accuracy of the questionnaire submitted. Subsequently, after validity and reliability tests have been carried out, it has been expanded by performing a classic assumption test, which aims to provide certainty that the regression equation obtained consistent, unbiased and reliable estimation accuracy.

Why is the classical assumption test important? Because a model can be called a good model in the classical assumption test if the model meets the criteria of the Best Linear Unbiased Estimator (BLUE). BLUE has been reached if it satisfies the classical assumptions. There are several research practices in the classical hypothesis method, such as multicollinearity, heteroscedasticity, and normality, which have the function and usefulness of each testing. After the classical assumption test, followed by a path analysis with functions to analyze the inherent causes by using path coefficients to determine the amount of influence of exogenous variables on endogenous variables. The structure for the proposed equations of path analysis are as follow:

$$
\begin{gathered}
\mathrm{Y}_{1}=\mathrm{C}+\mathrm{PY}_{1} \mathrm{X}_{1}+\mathrm{PY}_{1} \mathrm{X}_{2}+\mathrm{e}_{1} \\
\mathrm{Y}_{2}=\mathrm{C}+\mathrm{PY}_{2} \mathrm{X}_{1}+\mathrm{PY}_{2} \mathrm{Y}_{1}+\mathrm{PY}_{2} \mathrm{X}_{2}+\mathrm{e}_{2}
\end{gathered}
$$

where:

C - constant;

$\mathrm{P}$ - path coefficient;

$X_{1}$ - soft skills (Intrapersonal skills);

$\mathrm{X}_{2}$ - soft skills (Interpersonal skills);

$\mathrm{Y}_{1}$ - work motivation;

$\mathrm{Y}_{2}$ - employee performance

e - residual.

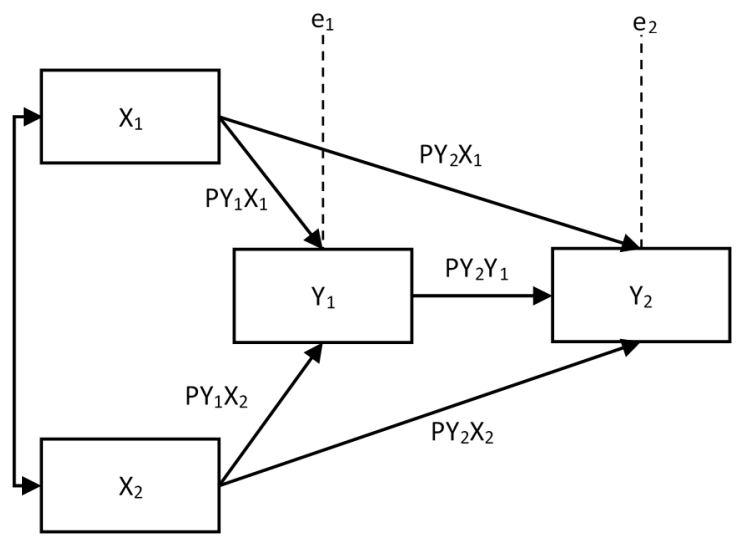

Figure 2. Path analysis diagram

Source: own elaboration. 
The study uses information collected based on two types of data categories primary and secondary data obtained from the relevant sources. Primary data collected employing a questionnaire exclusively carried out by PMP Company employees appointed as production executors by terms of a purposeful sampling method, while secondary data derived from company documentation and scientific and relevant literature for study, in particular, those related to soft skills, motivation, and employee performance. The ordinal scale is used to calculate the outcomes of the questionnaire using the Likert Summary Scale, which provides five elective answers: 1 (strongly disagree); 2 (disagree); 3 (neutral); 4 (agree) and 5 (strongly agree).

\section{The Case Company}

The PMP Company is a company engaged in pulp production in the province of Riau, Indonesia, with a total workforce of 183 permanent employees (excluding contractors). PMP Company produces pulp with an installed production capacity of 30,000 tons per month, which is then used as raw material for the manufacture of domestic paper and tissue that is also imported into various countries in Asia, Europe and America.

\section{Research sampling}

The target population of the study was all PMP employees with 183 employees, while the sample used was employees who worked as process operators with 121 employees in the production area. Nonetheless, only 112 respondents were willing to participate in the questionnaire. Based on the demographic data of the respondents in Tables 1 and 2 , from the number of respondents participating in the survey $(\mathrm{N}=112), 105$ male respondents (93.75\%) and only 7 females (6.25\%) participated. In comparison, when viewed from the age category, the average age of workers as respondents remains 36.14 years with a standard deviation of 8.491. In the average, age range of respondents from 20 to 53 years of age. The most influential respondents were between 30 to 40 years of age, 52 ( $46.43 \%)$ followed by 20 to 30 years of age, $27(24.11 \%)$. The remaining 40 to 50 years of age, $20(17.86 \%)$ and only 13 respondents (11.61\%) who are older than 50 years of age.

In the education level category, the largest number of respondents for high school education was as high as 50 (44.64\%), 38 (33.93\%) had Diploma Education certificates, and the remaining 24 (21.43\%) had Graduate degree Education as their academic degrees. In addition to the work experience of 4 to 25 years, the average working duration is 13.01 years with a standard deviation of 5.519. Participants with service years between 10 to 15 with a total of $42(37.50 \%)$, followed by respondents with service years between 5 to 10 years, $27(24.11 \%)$. In the meantime, respondents with more than 20 years of experience are $13(11.61 \%)$ and the workers with $0-5$ years of work. Subsequently, seen from the class of position held by the respondents who worked as production executors, the lowest level was as a machine operator with a dominant number of 76 (67.86 \%) followed by one level higher position, a team leader of $24(21.43 \%)$. The remains were populated with one level higher than the team leader, with $12(10.71$ $\%)$ as supervisors. 
Table 1. Respondent demographics

\begin{tabular}{|c|c|c|c|}
\hline \multicolumn{2}{|c|}{ Description of respondents $(\mathrm{N}=112)$} & Frequency & Percent \\
\hline \multirow[t]{4}{*}{ Age } & $20-30$ years & 27 & 24.11 \\
\hline & $31-40$ years & 52 & 46.43 \\
\hline & $41-50$ years & 20 & 17.86 \\
\hline & $>50$ years & 13 & 11.61 \\
\hline \multirow[t]{2}{*}{ Gender } & Male & 105 & 93.75 \\
\hline & Female & 7 & 6.25 \\
\hline \multirow[t]{3}{*}{ Educational level } & High School & 50 & 44.64 \\
\hline & Diploma & 38 & 33.93 \\
\hline & Graduate & 24 & 21.43 \\
\hline \multirow[t]{5}{*}{ Work experience } & $0-5$ years & 10 & 8.93 \\
\hline & $5-10$ years & 27 & 24.11 \\
\hline & $10-15$ years & 42 & 37.50 \\
\hline & $15-20$ years & 20 & 17.86 \\
\hline & $>20$ years & 13 & 11.61 \\
\hline \multirow[t]{3}{*}{ Level of job position } & Machine operator & 76 & 67.86 \\
\hline & Team Leader & 24 & 21.43 \\
\hline & Supervisor & 12 & 10.71 \\
\hline
\end{tabular}

Source: PMP Company.

Table 2. The Mean and standard deviation of respondent demographics

\begin{tabular}{|c|c|c|c|}
\hline Category & $\mathbf{N}$ & Mean & Std. Deviation \\
\hline Age & 112 & 36.14 & 8.491 \\
\hline Gender & 112 & 1.06 & 0.243 \\
\hline Educational level & 112 & 1.77 & 0.782 \\
\hline Work experience & 112 & 13.01 & 5.519 \\
\hline Level of job position & 112 & 1.43 & 0.681 \\
\hline
\end{tabular}

$\mathrm{N}=112$.

Source: own study.

\section{RESEARCH FINDINGS \& DISCUSSION}

\section{Validity test}

Validity analysis carried out to assess valid or invalid questionnaires. This study also uses the Pearson correlation coefficient, by measuring the correlation between items with cumulative scores from existing constructs: soft skills 39 statements (consisting of 24 intrapersonal skills and 15 interpersonal skills statements), then 10 statements for motivation variable and 10 statements for employee performance variable.

Based on the results of the validity test it was noted that four statements of intrapersonal skills variables were invalid because they had a significant value below 0.05 $(5 \%)$ and those four statements were omitted from the questionnaire. Because there is a reduction, the statement items used for intrapersonal skills adjust from the previous 24 statements to the 20 statements used. Subsequently, after measurements, the four measured variables are valid (because the Pearson correlation value exceeds 0.05 ) and can be further analyzed. 


\section{Reliability test}

After these variables were tested by the validity test, the consistency test was later performed to evaluate whether or not the questionnaire was considered reliable based on decisions on reliability. Assuming the statements made by the respondents are consistent over time, the construct values said to be reliable or consistent if the Cronbach Alpha value is $\geq$ 0.60 , and vice versa, if the Cronbach Alpha value is $<0.60$, it is considered non-reliable.

The reliability test results in Table 3 show that the alpha value of Cronbach is $\geq 0.60$ of the four variables evaluated. It ensures that variables such as intrapersonal skills (Cronbach's Alpha $=0.895)$, interpersonal skills (Cronbach's Alpha $=0.848$ ), motivation (Cronbach's Alpha $=0.796$ ) and employee performance (Cronbach's Alpha $=0.846$ ) are reliable use in data processing.

Table 3. Reliability test result

\begin{tabular}{|c|c|}
\hline Variables & Cronbach's Alpha \\
\hline Intrapersonal skills & 0.895 \\
\hline Interpersonal skills & 0.848 \\
\hline Motivation & 0.796 \\
\hline Employee performance & 0.846 \\
\hline
\end{tabular}

Source: own study.

\section{Classic assumption test}

\section{Multicollinearity test}

Multicollinearity testing performed to check whether there are intercorrelations between independent variables in the regression model. Interrelation is a linear relationship between predictor variables and other predictor variables. Interrelation has shown by the correlation coefficient between the independent variable, the VIF value and the tolerance.

Table 4. Multicollinearity test result

\begin{tabular}{|c|c|c|c|}
\hline Collinearity Stat. & Intrapersonal Skills $\left(\mathbf{X}_{\mathbf{1}}\right)$ & Interpersonal Skills $\left(\mathbf{X}_{\mathbf{2}}\right)$ & Motivation $\left(\mathbf{Y}_{\mathbf{1}}\right)$ \\
\hline Tolerance & 0.614 & 0.641 & 0.819 \\
\hline VIF & 1.628 & 1.560 & 1.221 \\
\hline
\end{tabular}

Source: own study.

The results of the multicollinearity test indicate that the tolerance values and VIFs in Table 4, based on the measurement tests, are $0.614,0.641$ and 0.819 for intrapersonal skills $\left(X_{1}\right)$, interpersonal skills $\left(X_{2}\right)$ and motivation $\left(Y_{1}\right)$ where the value is $>0.10$. The VIF value for intrapersonal skills $\left(X_{1}\right)$ variables is 1,628 , interpersonal skills $\left(X_{2}\right)$ are 1,560 and motivation $\left(\mathrm{Y}_{1}\right)$ variables are 1,221. The three values of VIF are $<10$. Subsequently, referring to the decision-making basis found in the multicollinearity test, it concluded that there are no signs of multicollinearity in the regression model.

\section{Heteroscedasticity test}

The presence of heteroscedasticity symptoms or problems will result in inaccuracies in the outcome of the regression analysis conducted in this analysis. Heteroscedasticity analysis 
using the scatterplot diagram by following the requirements where the data form a certain pattern, it is concluded that there is a heteroscedasticity disorder. Furthermore, if the data do not form a certain pattern and the point spreads on the $\mathrm{Y}$-axis at the top and bottom of the number 0 , it was assumed that there was no interference with heteroscedasticity.

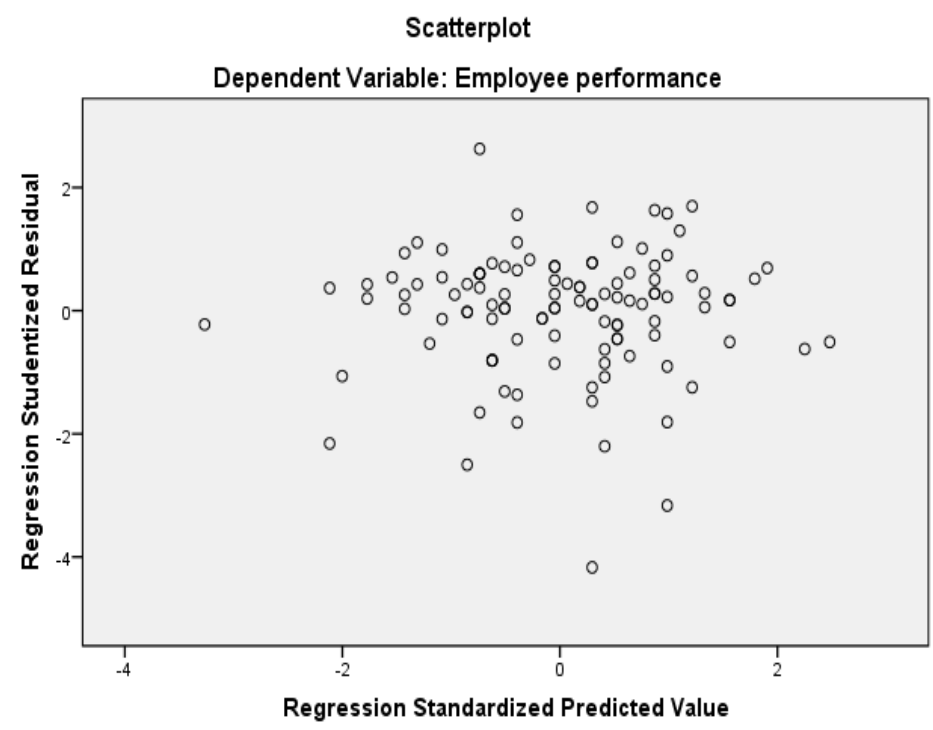

Figure 3. Scatterplot diagram $-X_{1}$

Source: own elaboration.

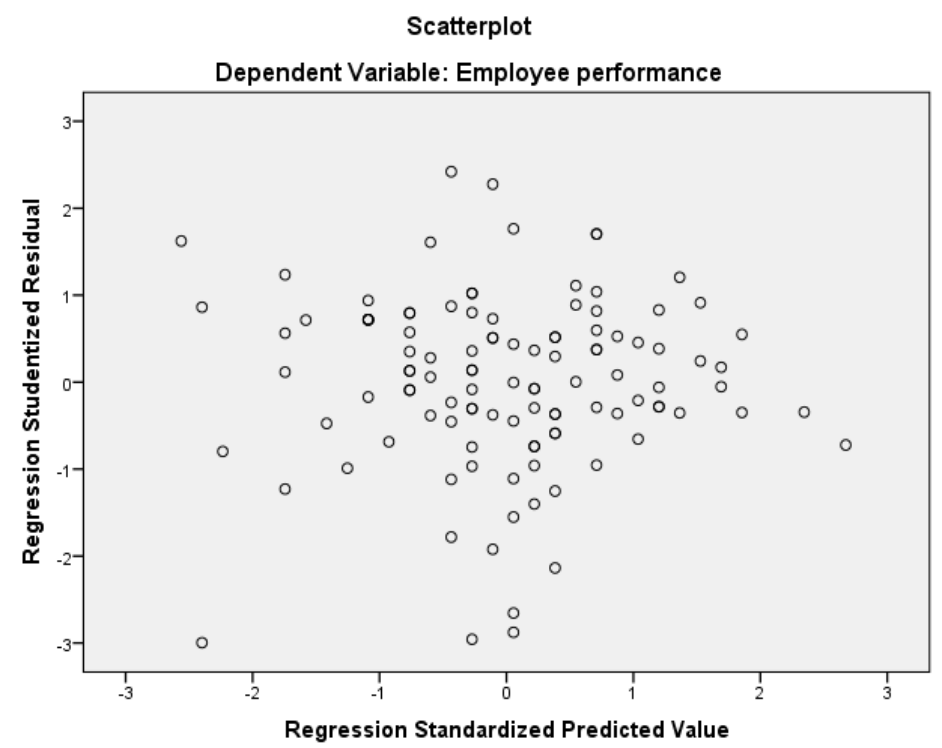

Figure 4. Scatterplot diagram - $\mathrm{X}_{2}$

Source: own elaboration. 


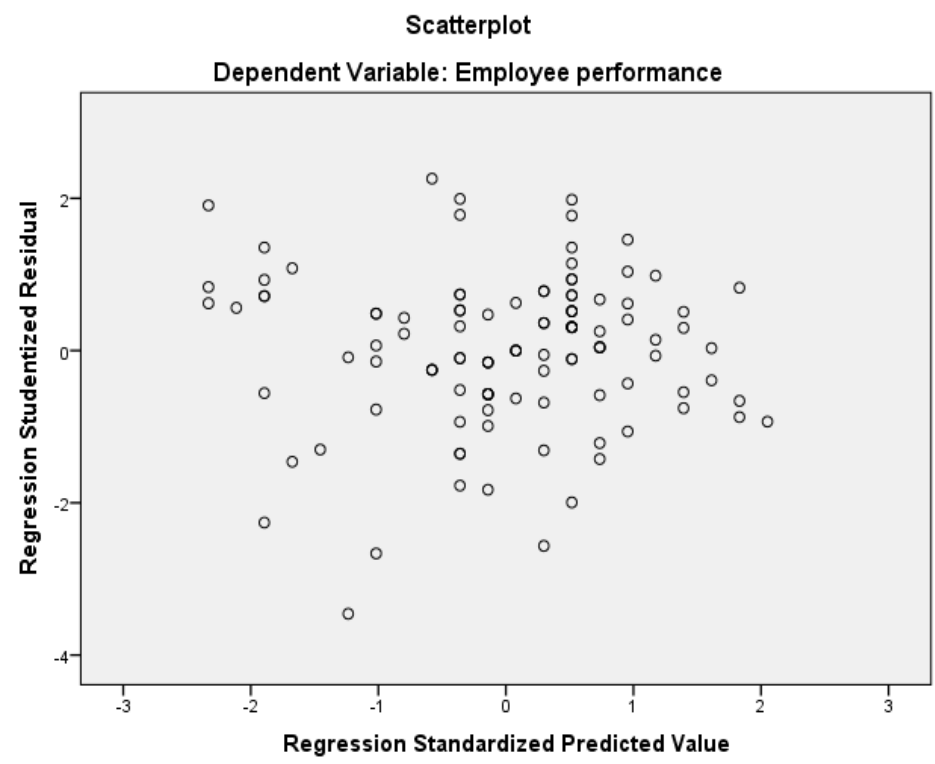

Figure 5. Scatterplot diagram $-Y_{1}$

Source: own elaboration.

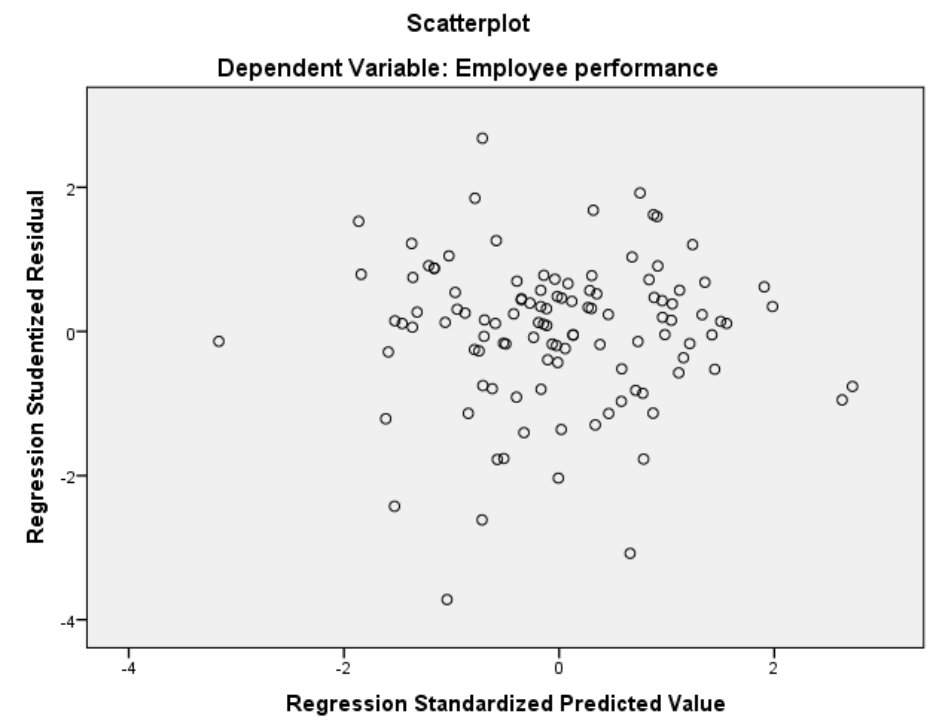

Figure 6. Scatterplot diagram $-X_{1}, X_{2}$ and $Y_{1}$

Source: own elaboration.

Based on the test results from the scatterplot diagram (as shown in Figs. 3, 4, 5 and 6) between SRESID and ZPRED, the $\mathrm{Y}$-axis is the $\mathrm{Y}$-axis that has been projected and the $\mathrm{X}$-axis 
is the residual that has been standardized. Showing the point spreading randomly, not creating a certain clear pattern, and scattering the $\mathrm{Y}$-axis up and down to zero. The distribution of data points does not form a wave pattern, but then narrows and widens again. This concluded that there were no symptoms of heteroscedasticity in the regression model. As a result, this regression model was good, ideal and feasible to use.

\section{Normality test}

Table 5. Normality test result

\begin{tabular}{|l|r|c|c|c|c|}
\hline \multirow{2}{*}{ Variables } & $\begin{array}{c}\text { Intrapersonal } \\
\text { Skills }\end{array}$ & $\begin{array}{c}\text { Interpersonal } \\
\text { Skills }\end{array}$ & Motivation & $\begin{array}{c}\text { Employee } \\
\text { Performance }\end{array}$ \\
\cline { 3 - 6 } & & $\mathbf{X}_{\mathbf{1}}$ & $\mathbf{X}_{\mathbf{2}}$ & $\mathbf{Y}_{\mathbf{1}}$ & $\mathbf{Y}_{\mathbf{2}}$ \\
\hline \multirow{2}{*}{ Kolmogorov-Smirnov } & Statistic & 0.081 & 0.071 & 0.118 & 0.108 \\
\cline { 2 - 6 } & $\mathbf{S i g}$ & 0.069 & 0.200 & 0.101 & 0.103 \\
\hline \multirow{2}{*}{ Shapiro-Wilk } & Statistic & 0.99 & 0.989 & 0.963 & 0.957 \\
\cline { 2 - 6 } & Sig & 0.582 & 0.538 & 0.103 & 0.111 \\
\hline
\end{tabular}

$\mathrm{df}=112$.

Source: own study.

The normality test used to figure out how the data are distributed. The argument is whether the independent and dependent variables in a good regression model are regression models with a normal or near-normal distribution. In the four variables that carried out the normality test in Table 5, the significance value ( $p$ ) of the Kolmogorov-Smirnov test were intrapersonal skills with sig value. 0.069 , intra-personal skills with sig. 0.200 , motivation with sig 0.101 and the sig. 0.103 on the performance of employees. Based on the Kolmogorov-Smirnov test results for these variables with output values $>0.05$, it was concluded that the data were properly distributed.

The assumption of normality in the regression model has therefore been fulfilled. Besides, this also confirmed the outcomes of the Shapiro-Wilk test by evaluating the outcome of each variable as follows: intra-personal skills with sig. 0.582 , interpersonal skills 0.538 , motivation sig. 0.103 and the performance of employees with sig. 0.111 . As a result, with all the values of the importance of variables $>0.05$, it is summarized that the data are properly distributed.

\section{Hypothesis test}

Path coefficient analysis for each variable used to test the hypothesis proposed to assess the direct effect of each of these variables. According to Table 6, it is understood that the value of $t$ sig, from variables $X_{1}$ and $X_{2}$ to $Y_{1}$, is $X_{1}=0.007$ and $X_{2}$ is 0.1 for the calculation of the path coefficient $Y_{1}=C+P Y_{1} X_{1}+P Y_{1} X_{2}+P Y_{1} X_{1}+P Y_{1}$. It concluded that only $X_{1}$ variables partially cause a significant impact on $Y_{1}$ in this regression model. The regression model has an $F$ test value (Anova) with a sig value. 0.000 , which means that $X_{1}$ and $X_{2}$ influence $Y_{1}$ simultaneously. The $R$ square value provided is equal to 0.181 , which indicates that the contribution of the influence of $X_{1}$ and $X_{2}$ to $Y_{1}$ is $18.1 \%$, while the remaining is the contribution of other variables not included in this study, while for the value of e1=0.181=0.904. Therefore, the first regression model developed with a constant value $=18,690$ : $Y_{1}=18.690 C+0.296 P Y_{1} X_{1}+0.178 P Y_{1} X_{2}+0.904 e_{1}$ 
Table 6. Path coefficient - test result

\begin{tabular}{|c|c|c|c|c|c|}
\hline \multicolumn{2}{|l|}{ Model } & $\beta$ & F Sig. & t - Sig. & R square \\
\hline Intrapersonal Skills & $X_{1}$ & 0.296 & \multirow{3}{*}{0.000} & 0.007 & \multirow{3}{*}{0.181} \\
\hline Interpersonal Skills & $\mathrm{X}_{2}$ & 0.178 & & 0.100 & \\
\hline Motivation & $Y_{1}$ & - & & - & \\
\hline Intrapersonal Skills & $\mathrm{X}_{1}$ & 0.303 & \multirow{3}{*}{0.000} & 0.05 & \multirow{3}{*}{0.219} \\
\hline Interpersonal Skills & $x_{2}$ & 0.221 & & 0.037 & \\
\hline Employee Performance & $Y_{2}$ & - & & - & \\
\hline Intrapersonal Skills & $X_{1}$ & 0.286 & \multirow{4}{*}{0.000} & 0.009 & \multirow{4}{*}{0.221} \\
\hline Interpersonal Skills & $x_{2}$ & 0.211 & & 0.049 & \\
\hline Motivation & $\mathrm{Y}_{1}$ & 0.055 & & 0.047 & \\
\hline Employee Performance & $\mathrm{Y}_{2}$ & - & & - & \\
\hline
\end{tabular}

Source: own study.

In the next regression model, the equation of $Y_{2}=C+P Y_{2} X_{1}+P Y_{2} Y_{1}+P Y_{2} X_{2}+e_{2}$, the value of $t$ sig. The three variables obtained are $X_{1}=0.009, X_{2}=0.049$ and $Y_{1}=0.047$, then based on the value of $t$ sig. It was found that the variables $X_{1}, X_{2}$, and $Y_{1}$ partially had a significant effect on $Y_{2}$. In contrast, the $F$ check value (Anova) with a value of 0.000 means that the $X_{1}, X_{2}$, and $Y_{1}$ variables simultaneously have a significant effect on $Y_{1}$. The $R$ square value obtained is equal to 0.221 , meaning that the contribution of variables $X_{1}, X_{2}$, and $Y_{1}$ to $Y_{2}$ is $22.1 \%$, while the rest of the variables are not examined for contributions from other variables. For the use of the $e_{2}$ obtained $e_{2}=1-0.221$ ) $=0.882$. Regression models built with constant values $=14,876$ are as follows:

$$
\mathrm{Y}_{2}=14.876 \cdot \mathrm{C}+0.286 \cdot \mathrm{PY}_{2} \mathrm{X}_{1}+0.211 \cdot \mathrm{PY}_{2} \mathrm{Y}_{1}+0.055 \cdot \mathrm{PY}_{2} \mathrm{X}_{2}+0.882 \cdot \mathrm{e}_{2}
$$

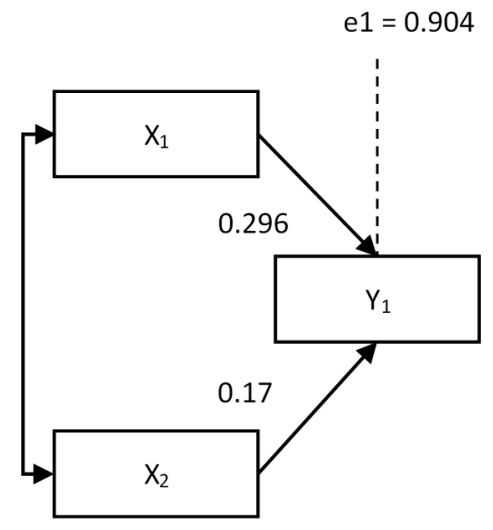

Figure 7. Path diagram $\mathbf{Y}_{1}=\mathrm{C}+\mathrm{PY}_{1} \mathrm{X}_{1}+\mathrm{PY}_{1} \mathrm{X}_{2}+\mathrm{e}_{1}$

Source: own elaboration. 


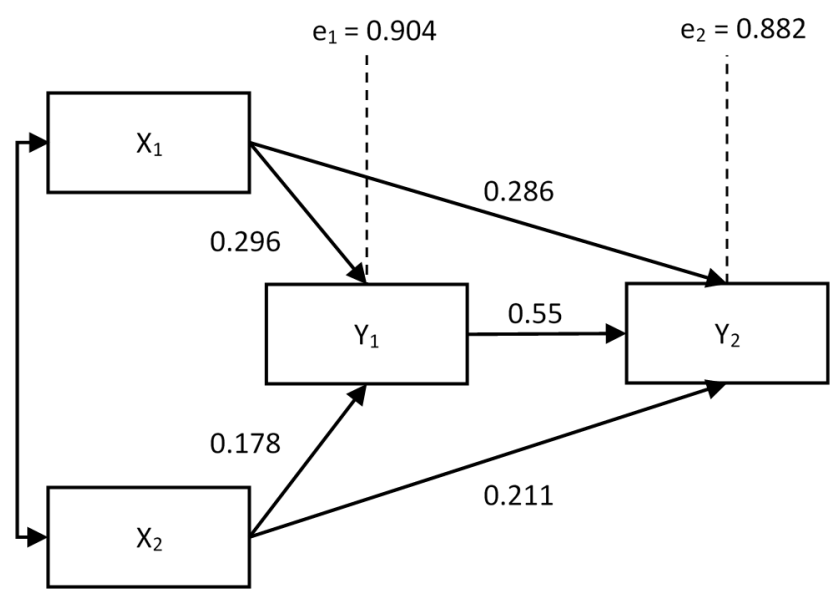

Figure 8. Path diagram $\mathbf{Y}_{2}=\mathbf{C}+\mathbf{P Y}_{2} \mathbf{X}_{1}+\mathbf{P Y}_{2} \mathbf{Y}_{1}+\mathbf{P Y}_{2} \mathbf{X}_{2}+\mathbf{e}_{2}$ Source: own elaboration.

After the hypothesis test has been completed, the outcome is conceptually summarized in Table 7 with the following explanation.

Table 7. Hypotheses test result

\begin{tabular}{|c|c|c|}
\hline \multicolumn{2}{|r|}{ Hypotheses and explanations } & Verification \\
\hline \multirow{2}{*}{ H1 } & $\begin{array}{l}\text { Intrapersonal skills and interpersonal skills have a positive influence on } \\
\text { work motivation }\end{array}$ & \multirow{2}{*}{ Accepted } \\
\hline & $\begin{array}{l}\text { This is shown by the positive value found in the } \beta=0.296\left(X_{1}\right) \text { and } 0.178 \\
\left(X_{2}\right) \text { path coefficients. Subsequently, the } H 1 \text { statement is accepted. }\end{array}$ & \\
\hline \multirow[b]{2}{*}{$\mathrm{H} 2$} & $\begin{array}{l}\text { Intrapersonal skills and interpersonal skills have a positive influence on } \\
\text { employee performance }\end{array}$ & \multirow[b]{2}{*}{ Accepted } \\
\hline & $\begin{array}{l}\text { Hypothesis } 2 \text { with positive path coefficient values for variables } X_{1} \text { and } X_{2} \\
\text { towards } Y_{2} \text {, i.e.: } X_{1}=0.303 \text { and } X_{2}=0.221 \text {, with the result that the state- } \\
\text { ment in } H_{2} \text { is accepted. }\end{array}$ & \\
\hline \multirow[b]{2}{*}{ H3 } & $\begin{array}{l}\text { Intrapersonal skills and interpersonal skills through work motivation } \\
\text { have a positive influence on employee performance. }\end{array}$ & \multirow[b]{2}{*}{ Accepted } \\
\hline & $\begin{array}{l}\text { The path coefficient values of the variables } X_{1}, X_{2} \text { and } Y_{1} \text { towards } Y_{2} \text { are } \\
\text { positive, i.e. } X_{1}=0.286, X_{2}=0.211 \text { and } Y_{1}=0.055 \text {. The hypothesis of } H 3 \text { is } \\
\text { therefore accepted. }\end{array}$ & \\
\hline
\end{tabular}

Source: own study.

The direct and indirect impacts of variables on employee performance

The direct and indirect effects discussed in Table 8 below indicate that each variable $X 1$, $\mathrm{X} 2$, and $\mathrm{Y} 1$ has a direct impact on the variable $\mathrm{Y} 2$. The cumulative direct impact value is 0.497 and the indirect impact value is 0.529 . It indicates that the indirect impact has a greater impact than the direct impact. 
Table 8. Direct and indirect impact

\begin{tabular}{|c|c|c|}
\hline \multirow{2}{*}{ Variables } & \multicolumn{2}{|c|}{ Employee performance } \\
\hline & Direct impact & Indirect impact \\
\hline Intrapersonal skills & 0.286 & 0.296 \\
\hline Interpersonal skills & 0.211 & 0.178 \\
\hline Motivation & - & 0.055 \\
\hline Total influence & 0.497 & 0.529 \\
\hline
\end{tabular}

Source: own study.

\section{CONCLUSIONS, IMPLICATION \& LIMITATION}

\section{Conclusion}

After evaluating the three hypotheses suggested in this report, it concluded:

- First, the test of Hypothesis 1, which indicates that there is a positive influence on motivation between intrapersonal skills and interpersonal skills, although only partially intrapersonal skills have a significant influence. At the same time, however, the variables of $X_{1}$ and $X_{2}$ have a significant influence on motivation.

- Second, the results of the tests performed on the hypothesis with the statement submitted that there are positive influences of intrapersonal skills and interpersonal skills on employee performance have shown to be accepted.

- Third, Hypothesis 3, which notes that there is a positive influence on motivation between intrapersonal skills and interpersonal skills and has an influence on employee performance, has shown to have a positive path coefficient value. The findings of the partial variable test (t-test) and the simultaneous test (F-test) obtained by achieving significant results.

\section{Theoretical implication}

The theoretical implications of this study are the increase in research references on soft skills, motivation and employee performance, primarily in manufacturing firms and in pulp manufacturing companies in particular. Another theoretical implication is to promote the development of organizational behavior studies, which can then consider organizational and personal factors that can improve the performance of employees. Based on these theoretical implications, it is proposed that future studies may use more varied or more detailed research variables on how the business optimizes its output factors to enhance organizational efficiency.

\section{Managerial implication}

Potential labor shortages due to soft skills deficiencies due to underinvestment in soft skills are expected to contribute to skill shortages where employers are unable to fill job vacancies, as they are unable to find candidates with appropriate skills and fail to improve existing employees to meet global challenges. This study has implications for the creation of understanding among companies, in particular, those engaged in the field of industry, to change their policy and operational approaches. Primarily to strengthen soft skills that go hand in hand with growing hard skills, to promote encouragement to take the effect of the 
overall performance of employees and organizations to thrive and indeed grow in the current era of global competition.

\section{Limitation}

This study recognizes limitations as it has only been performed in one pulp manufacturing company. The findings of the study may be different if the scope of the research is different and applied to other manufacturing companies. Another drawback is that this research gives priority to data processing approaches using information obtained from questionnaires distributed to respondents so that the emotional state of the participants at the time the questionnaire was completed is uncertain and the variables chosen are limited.

\section{REFERENCES}

Abdalkrim, G. M. (2013). The Impact of Strategic Planning Activities on Private Sector Organizations Performance in Sudan: An Empirical Research. International Journal of Business and Management, 8(10), 134-143. https://doi.org/10.5539/ijbm.v8n10p134

Altındağ, E., \& Kösedağı, Y. (2015). The Relationship Between Emotional Intelligence of Managers, Innovative Corporate Culture and Employee Performance. Procedia - Social and Behavioral Sciences, 210, 270-282. https://doi.org/10.1016/j.sbspro.2015.11.367

Anderson, J. C., Rungtusanatham, M., \& Schroeder, R. G. (1994). a Theory of Quality Management Underlying the Deming Management Method. Academy of Management Review, 19(3), 472 509. https://doi.org/10.5465/amr.1994.9412271808

Cimatti, B. (2016). Definition, development, assessment of soft skills and their role for the quality of organizations and enterprises. International Journal for Quality Research, 10(1), 97-130. https://doi.org/10.18421/IJQR10.01-05

De Prins, P., Van Beirendonck, L., De Vos, A., \& Segers, J. (2014). Sustainable HRM: Bridging theory and practice through the 'respect openness continuity (ROC)'-model. Management Revue, 25(4), 263-284. https://doi.org/10.1688/mrev-2014-04-Prins

Dean, S., \& East, J. (2019). Soft Skills Needed for the 21st-Century Workforce. International Journal of Applied Management and Technology, 18(1), 5. https://doi.org/10.5590/IJAMT.2019.18.1.02

Demirbag, M., Tatoglu, E., Tekinkus, M., \& Zaim, S. (2006). An analysis of the relationship between TQM implementation and organizational performance: Evidence from Turkish SMEs. Journal of Manufacturing Technology Management, 17(6), 829-847. https://doi.org/10.1108/17410380610678828

Development of Economics. (2015). the Value of Soft Skills to the UK Economy. The United Kingdom.

Dietrich, J., Parker, P., \& Salmela-Aro, K. (2012). Phase-adequate engagement at the post-school transition. Developmental Psychology, 48(6), 1575-1593. https://doi.org/10.1037/a0030188

Ehnert, I., Harry, W., \& Zink, K. J. (2013). Sustainability and Human Resource Management Developing Sustainable Business Organizations. In NHRD Network Journal (Vol. 6). https://doi.org/10.1177/0974173920130413

Firdaus, I. (2017). Urgensi Soft Skills dan Character Building Bagi Mahasiswa. Jurnal TAPIs, 14, 60-73.

Goodall Jr., H. L. (1992). Empowerment, culture, and postmodern organizing: Deconstructing the nordstrom employee handbook. Journal Organization Change and Management, 5(2), 25-30.

Hairi, F., Toee, M. N. A., \& Razzaly, W. (2011). Employers' Perception On Soft Skills Of Graduates: A Study Of Intel Elite Soft Skill Training. International Conference on Teaching \& Learning in Higher Education (ICTLHE 2011) Employers', (Ictlhe). 
Hendarman, A. F., \& Tjakraatmadja, J. H. (2012). Relationship among Soft Skills, Hard Skills, and Innovativeness of Knowledge Workers in the Knowledge Economy Era. Procedia - Social and Behavioral Sciences, 52, 35-44. https://doi.org/10.1016/j.sbspro.2012.09.439

Imran, R., Fatima, A., Zaheer, A., Yousaf, I., \& Batool, I. (2012). How to boost employee performance: Investigating the influence of transformational leadership and work environment in a Pakistani perspective. Middle East Journal of Scientific Research, 11(10), 1455-1462. https://doi.org/10.5829/idosi.mejsr.2012.11.10.741

Kaba, R., Ogink, A., Nketiah-amponsah, E., Alhassan, R. K., Spieker, N., Ostenberg, P. Van, ... Nketiahamponsah, E. (2013). Association between health worker motivation and healthcare quality efforts in Ghana Association between health worker motivation and healthcare quality efforts in Ghana. Human Resources for Health, 11(1), 1. https://doi.org/10.1186/1478-4491-11-37

Kanfer, R., \& Chen, G. (2016). Motivation in organizational behavior: History, advances and prospects. Organizational Behavior and Human Decision Processes, 136(September 2016), 619. https://doi.org/10.1016/j.obhdp.2016.06.002

Kooij, D. T. A. M., \& Kanfer, R. (2019). Lifespan Perspectives on Work Motivation. In Work Across the Lifespan (pp. 475-493). https://doi.org/10.1016/b978-0-12-812756-8.00020-7

Muqowim. (2012). Pengembangan Soft Skills Guru. Yogyakarta: Pedagogia.

Okoro, E., Cwashington, M., \& Thomas, O. (2017). The Impact of Interpersonal Communication Skills on Organizational Effectiveness and Social Self-Efficacy: A Synthesis. International Journal of Language and Linguistics, 4(3), 5. Retrieved on September 21, 2019 from www.ijllnet.com

Osman, S., Shariff, S. H., \& Lajin, M. N. A. (2016). Does Innovation Contribute to Employee Performance? Procedia - Social and Behavioral Sciences, 219, 571-579. https://doi.org/10.1016/j.sbspro.2016.05.036

Pinder, C. C. (1998). Work Motivation in Organizational Behavior (1998th ed.). Prentice Hall.

Robbins, S. T., Judge, T. A., \& Hasham, E. S. (2012). Organizational Behavior (13th ed.; F. Gibbons, Ed.). Retrieved on September 21, 2019 from http://www. pearsonmiddleeastawe.com/pdfs/OBSAMPLE.pdf

Sadikoglu, E., \& Zehir, C. (2010). Investigating the effects of innovation and employee performance on the relationship between total quality management practices and firm performance: An empirical study of Turkish firms. International Journal of Production Economics, Vol. 127, pp. 13-26. https://doi.org/10.1016/j.ijpe.2010.02.013

Seetha, N. (2014). Are Soft skills Important in the Workplace? â " A Preliminary Investigation in Malaysia. International Journal of Academic Research in Business and Social Sciences, 4(4), 4456. https://doi.org/10.6007/ijarbss/v4-i4/751

Vijayalakshmi, V. (2016). Soft Skills-The Need of the Hour for Professional Competence: A Review on Interpersonal Skills and Intrapersonal Skills Theories. International Journal of Applied Engineering Research, 11(4), 2859-2864. Retrieved on September 23, 2019 from https://pdfs.semanticscholar.org/2ff5/baed1a51942d446110017d9445d538922e24.pdf 


\section{Authors}

The contribution share of authors is equal and amounted to $50 \%$ each of them.

\section{Cheng-Wen Lee}

Professor in the Department of International Business, College of Business, Chung Yuan Christian University (CYCU) Taiwan. Research interests: International Business Management, International Marketing, International Marketing Management, and Global Logistics Management.

Correspondence to: Prof. Cheng-Wen Lee, Ph.D., Department of International Business, Chung Yuan Christian University, 200 Chung Pei Road, Chung Li District, Taoyuan City, 32023, Taiwan, ROC, e-mail: chengwen@cycu.edu.tw

ORCID (1) http://orcid.org/0000-0002-4811-7000

\section{Alum Kusumah}

Ph.D. Student in the Department of International Business, College of Business, Chung Yuan Christian University (CYCU) Taiwan. Research interest: International Business Management, Human Resources Management, Operational Management, and Organizational Behavior.

Correspondence to: Alum Kusumah, Chung Yuan Christian University, College of Business, 200 Chung Pei Road, Chung Li District, Taoyuan City, Taiwan 32023, R.O.C, e-mail: alumkusumah@gmail.com

ORCID (1) http://orcid.org/0000-0002-6710-5515

\section{Acknowledgements and Financial Disclosure}

The authors would like to thank the anonymous reviewers for their valuable reviews, which have improved the quality of this paper.

\section{Copyright and License}

This article is published under the terms of the Creative Commons

Attribution - NoDerivs (CC BY-ND 4.0) License

http://creativecommons.org/licenses/by-nd/4.0/

Published by the Centre for Strategic and International Entrepreneurship - Krakow, Poland 